\title{
An interventional study on the effectiveness of peer assistance for medication adherence among hypertensive patients in Purwokerto
}

\author{
Hening Pratiwi *, Laksmi Maharani, Ika Mustikaningtias, Eling Bunga Nurani \\ Department of Pharmacy, Faculty of Health Sciences Universitas Jenderal Soedirman Purwokerto \\ Jl. Dr. Soeparno Kampus Karangwangkal
}

Submitted: 08-03-2019

Reviewed: 05-04-2019

Accepted: 30-04-2019

\begin{abstract}
Hypertension is a disorder of the blood vessels that hampers the transport of supply of oxygen and nutrients to the body's tissues. Antihypertensive therapy lasts a lifetime and, so, the success of hypertension treatment strongly depends on the willingness of patients to take antihypertensives regularly. Since medical non-compliance can adversely affect the patient's health, medication supervision or peer assistance has been proposed as a way to monitor and remind hypertensive patients to adhere to prescribed daily dosage. This study aimed to determine the effect of peer assistance on adherence to hypertensive medication. It employed a quasi-experimental model with a one-group pretest-posttest design and a peer-based mentoring to achieve drug compliance as the intervention. The research samples were patients registered in the Chronic Disease Management Program (Program Pengelolaan Penyakit Kronis) at two primary health services in Purwokerto. In the first four weeks, a total of 29 respondents acted as the control group without receiving any intervention, and in the second four weeks, they became the intervention group who received peer assistance for their regular drug intake. To measure compliance, the Hill-Bone questionnaire was used. The expected maximum compliance score is 56. The results showed that the average score of compliance increased from 47.69 in the pre-control period to 49 in post-control/pre-intervention and then to 49.93 in post-intervention. The compliances during the control and intervention period had similarly significant differences with $p$ values of 0.008 and 0.039 , respectively. In conclusion, peer assistance does not affect patients' adherence to hypertension treatment.
\end{abstract}

Keywords: hypertension, peer assistance, antihypertensives, blood pressure, medication adherence

\footnotetext{
*Corresponding author:

Hening Pratiwi

Department of Pharmacy, Universitas Jenderal Soedirman

J1. Dr. Soeparno Kampus Karangwangkal

Email: hening.pratiwi@ymail.com
} 


\section{INTRODUCTION}

Hypertension is a chronic disease characterized by an increase in systolic blood pressure of more than $140 \mathrm{~mm} \mathrm{Hg}$ and/or diastolic blood pressure of more than $90 \mathrm{~mm} \mathrm{Hg}$ (Saseen and Carter, 2015). It has a high prevalence rate, namely $9.5 \%$ of the total population in Indonesia (in 2013) and $40-45 \%$ worldwide. The number of hypertensive patients increases by up to $0.32 \%$ per year. The high commonness makes hypertension as the top 10 diseases that are mostly handled at the primary health services in Banyumas Regency, with 5,575 cases alone in 2014 (Dinas Kesehatan Banyumas, 2015).

Hypertension is one of the main risk factors for renal and cerebrovascular disorders (Shen et al., 2016). Good blood pressure control can prevent hypertensive patients from the risk of mortality and morbidity due to complications from both disorders (Chobanian, 2003). To control blood pressure, patients can take pharmacological therapy using antihypertensives and non-pharmacological medication with diet, physical activity, and lifestyle (Filipovsky et al., 2014).

Antihypertensive drug therapy lasts a lifetime (Chobanian, 2003) and, therefore, the success of hypertension treatment is determined by the willingness of patients to take antihypertensive drugs regularly (Rahmawati and Mutmainah, 2010). More than $70 \%$ of outpatients do not comply with the appropriate dosage. According to the WHO report in 2003, the average adherence to long-term treatment of chronic diseases in developed countries was only $50 \%$ and even lower in developing countries. Another study has found that the compliance rate of hypertensive patients to consuming prescribed drugs properly is only 6.3\% (Putri, 2012). Non-compliance can harm the patient's health and result in the swelling of medical expenses or insurance cost in the hospital. In the case of hypertension, it can also increase the risk of uncontrolled blood pressure, complications of heart failure, stroke, and cardiovascular death (Yacob and Leonelo, 2015). Therefore, drug compliance must be improved with any efforts.

The Ministry of Health of the Republic of Indonesia recommends medication supervision or peer assistance for hypertensive patients to help them to follow through with their treatments. In this scheme, the peer is in charge of supervising, encouraging, and ensuring that patients take medication regularly. It must be someone who is known and trusted by patients, that is, family members or health workers who are willing to monitor and remind them to comply with the recommended therapy (Kemenkes RI, 2009; Depkes RI, 2009). The influence of peer assistance on adherence to antihypertensive treatment has been widely investigated. Peer assistance through short message service (SMS) is proven to improve drug compliance and blood pressure stability. Patients' adherence to hypertension treatment has doubled after receiving peer assistance services, which is followed by a decrease in systolic and diastolic blood pressure by $17.92 \pm 12.2 \mathrm{mmHg}$ and $9.17 \pm 8.9 \mathrm{mmHg}$, respectively (Alfian, 2015). Since medication supervision can improve drug compliance, it is likely to increase the success of the therapy (Yoisangadji et al., 2016; Firdaus, 2012). However, hypertension management has not implemented it as a strategy to improve the patient's compliance.

This research essentially determined the effect of peer assistance-an intervention-on medication compliance of hypertensive patients. Understanding this matter is useful to achieve cost efficiency in hypertension treatment. Blood pressure control and good adherence will prevent hypertension-related morbidity and mortality, such as complications to the heart, kidneys, and brain. Consequently, people's health, particularly those with hypertension, will be improved. This study aimed to determine the effect of peer assistance on treatment compliance of hypertensive patients at two clinics in Purwokerto.

Pharmaciana Vol. 9, No. 1, May 2019, Page. 99-108 


\section{METHODS AND MATERIALS}

\section{Materials}

The research used an informed consent, the Malay version of the Hill-Bone's questionnaire on compliance, digital tensimeter, and cellphone.

\section{Methods}

This research is an experimental study employing a one-group pretest-posttest design. Hypertensive patients who were willing to participate as respondents were selected with accidental sampling technique. At first, there were 34 respondents, but this number decreased to 29 patients because of some circumstances. The houses of the three patients were inaccessible to visitation, one patient resigned during the first visit, and another patient did not have the facility to receive SMS. The study was conducted for eight weeks: the first four weeks were the control period and the next four weeks were the intervention period. In the control period, the patients were not given any intervention, whereas in the intervention period, they received reminders through SMS and phone calls once a week. This study has received approval from the Research Ethics Committee of the Faculty of Medicine, Universitas Gadjah Mada (No. KE/FK/0570/EC/2018). Also, all respondents had given informed consent before participating in the study.

The data were collected using the modified Malay version of the Hill-Bone questionnaire on compliance (Cheong et al., 2015). The questionnaire was filled out three times, namely during precontrol, post-control/pre-intervention, and post-intervention.

Table I. Item scoring in the questionnaire on medication compliance

\begin{tabular}{|c|c|c|c|c|c|c|}
\hline Domains & No. & Questions/Items & Always & Often & Sometimes & Never \\
\hline \multirow[t]{3}{*}{$\begin{array}{l}\text { Natrium } \\
\text { Intake }\end{array}$} & 3 & $\begin{array}{l}\text { How often do you eat salted } \\
\text { food? }\end{array}$ & 1 & 2 & 3 & 4 \\
\hline & 4 & $\begin{array}{l}\text { How often do you add salt, } \\
\text { soy sauce, or sauce to your } \\
\text { food before eating it? }\end{array}$ & 1 & 2 & 3 & 4 \\
\hline & 5 & $\begin{array}{l}\text { How often do you eat fast } \\
\text { food? }\end{array}$ & 1 & 2 & 3 & 4 \\
\hline \multirow[t]{2}{*}{$\begin{array}{l}\text { Routine } \\
\text { Visit to the } \\
\text { Doctor }\end{array}$} & 6 & $\begin{array}{l}\text { How often do you make an } \\
\text { appointment for your next } \\
\text { visit before leaving the } \\
\text { clinic? }\end{array}$ & 4 & 3 & 2 & 1 \\
\hline & 7 & $\begin{array}{l}\text { How often do you miss the } \\
\text { scheduled appointment } \\
\text { (based on the proposed } \\
\text { schedule in the Chronic } \\
\text { Disease Management } \\
\text { Program)? }\end{array}$ & 1 & 2 & 3 & 4 \\
\hline \multirow{4}{*}{$\begin{array}{l}\text { Regularity } \\
\text { in } \\
\text { Medication } \\
\text { Intake }\end{array}$} & 1 & $\begin{array}{l}\text { How often do you forget to } \\
\text { take your high blood } \\
\text { pressure medicines? }\end{array}$ & 1 & 2 & 3 & 4 \\
\hline & 2 & $\begin{array}{l}\text { How often do you choose } \\
\text { not to take your high blood } \\
\text { pressure medicines? }\end{array}$ & 1 & 2 & 3 & 4 \\
\hline & 8 & $\begin{array}{l}\text { How often do you forget to } \\
\text { repeat your treatment? }\end{array}$ & 1 & 2 & 3 & 4 \\
\hline & 9 & $\begin{array}{l}\text { How often do you run out of } \\
\text { high blood pressure } \\
\text { medicines? }\end{array}$ & 1 & 2 & 3 & 4 \\
\hline
\end{tabular}




\begin{tabular}{|c|c|c|c|c|c|c|}
\hline Domains & No. & Questions/Items & Always & Often & Sometimes & Never \\
\hline \multirow[t]{5}{*}{$\begin{array}{l}\text { Regularity } \\
\text { in } \\
\text { Medication } \\
\text { Intake }\end{array}$} & 10 & $\begin{array}{l}\text { How often do you stop } \\
\text { taking high blood pressure } \\
\text { medicines before seeing a } \\
\text { doctor? }\end{array}$ & 1 & 2 & 3 & 4 \\
\hline & 11 & $\begin{array}{l}\text { How often do you choose } \\
\text { not to take your high blood } \\
\text { pressure medicines when } \\
\text { you feel healthy? }\end{array}$ & 1 & 2 & 3 & 4 \\
\hline & 12 & $\begin{array}{l}\text { How often do you choose } \\
\text { not to take your high blood } \\
\text { pressure medicines when } \\
\text { you feel sick? }\end{array}$ & 1 & 2 & 3 & 4 \\
\hline & 13 & $\begin{array}{l}\text { How often do you take } \\
\text { someone else high blood } \\
\text { pressure medicines? }\end{array}$ & 1 & 2 & 3 & 4 \\
\hline & 14 & $\begin{array}{l}\text { How often do you forget to } \\
\text { bring your high blood } \\
\text { pressure medicines when } \\
\text { you are traveling away from } \\
\text { home? }\end{array}$ & 1 & 2 & 3 & 4 \\
\hline
\end{tabular}

\section{Data Analysis}

The scores of the answers provided by respondents during the survey were analyzed as the primary research data using the Wilcoxon test. This test was selected because the data were not distributed normally.

\section{Results and Discussion}

\section{The Characteristics of the Respondents}

Based on the data presented in Table II, the respondents consist of female (65.5\%) more than male $(34.5 \%)$. The majority of the female respondents are 45 years old and above, meaning that they may have entered menopause. Women have more estrogen than men, but when they enter menopause their estrogen production decreases. The lack of this hormone can reduce the flexibility of blood vessels (i.e., to relax and accommodate blood flows) and, therefore, trigger an increase in blood pressure (Gudmundsdottir et al., 2012).

The number of elderly respondents ( $\geq 65$ years old) is higher than those of adult (45-59 years old) and middle age (60-64 years old). Blood pressure increases slowly with age because of arterial stiffness and lumen narrowing (Gumi et al., 2013). Patients with high education degrees are the fewest, which is in line with Agrina et al. (2011) who state that level of education can affect one's ability and knowledge in implementing healthy behaviors that can prevent, for instance, hypertension. The higher the education level attained by the patients, the easier they are to receive information and the more knowledge they have, which can increase their ability to maintain a lifestyle (Agrina et al., 2011).

In this study, there are more unemployed respondents than employed ones. Individuals with low activity have $30-50 \%$ higher risk of hypertension than active individuals (Agrina et al., 2011). 
Table II. The characteristics of the respondents

\begin{tabular}{|c|c|c|c|}
\hline No & Characteristics & $\begin{array}{l}\sum_{\text {Respondents }} \\
\end{array}$ & $\begin{array}{l}\text { Percentage } \\
(\%)\end{array}$ \\
\hline \multirow[t]{4}{*}{1} & Sex & & \\
\hline & Female & 19 & 65.5 \\
\hline & Male & 10 & 34.5 \\
\hline & Total & 29 & 100 \\
\hline \multirow[t]{5}{*}{2} & Age & & \\
\hline & Adult (45-59 years old) & 9 & 31 \\
\hline & $\begin{array}{l}\text { Middle Age (60-64 years } \\
\text { old) }\end{array}$ & 6 & 20.7 \\
\hline & Old (65-90 years old) & 14 & 48.3 \\
\hline & Total & 29 & 100 \\
\hline \multirow[t]{6}{*}{3} & Educational Attainment & & \\
\hline & Elementary School (SD) & 4 & 13.8 \\
\hline & Junior High School (SMP) & 7 & 24.1 \\
\hline & Senior High School (SMA) & 13 & 44.8 \\
\hline & Higher Education & 5 & 17.2 \\
\hline & Total & 29 & 100 \\
\hline \multirow[t]{4}{*}{4} & Employment Status & & \\
\hline & Employed & 6 & 20.7 \\
\hline & Unemployed & 23 & 79.3 \\
\hline & Total & 29 & 100 \\
\hline
\end{tabular}

\section{The Medication Adherence Level of the Respondents}

The compliance score ranges between 14 and 56. A higher score represents better medication adherence. The results showed that the average compliance during the pre-control period was 47.69. Meanwhile, during the post-control/pre-intervention and the post-intervention periods, the scores were 49 and 49.93, respectively. The score difference confirms that there is an improvement in compliance throughout the research. However, an increase in compliance scores during the control period (1.31) was higher than the intervention period (0.93).

Patient's compliance was also observed from the score of each questionnaire item. The maximum score of each item is 116 , that is, by multiplying the maximum score of the answer (4) with the number of respondents (29). Meanwhile, the minimum score is 29 , which is the multiplication of the minimum score of the answer (1) with the number of respondents (29). Question No. 1 about how often patients forget to take high blood pressure medication showed a slight decrease in scores from the pre-control to post-control period, but these scores increased after the peer assistance intervention. Such a reduction may be caused by the majority of elderly respondents - aged 60 years and older (69\%). Memory tends to decline as people age (Mursiany et al., 2013). Consequently, many of the respondents forgot to take their medicine. Questions No. 2 (the patient's decision to not take medicines), No. 10 (how often patients stop taking antihypertensives before seeing a doctor), and No. 13 (how often patients take other's antihypertensives) showed an increase in scores both during the control and intervention periods. The increase was higher in the control period than the intervention period. Women make up for $65.5 \%$ of the respondents. Compared with men, women usually pay more 
attention to their health (Depkes RI, 2013). According to Ramli et al. (2012), almost half of the female respondents are more obedient to treatment than the male respondents. Therefore, increased scores of Questions No. 2, 10, and 13 before and after intervention in the form of peer assistance are likely caused by the characteristics of the respondents who are mostly women.

Table III. The Average Score and Percentage of the Residents' Compliance

\begin{tabular}{cccc}
\hline & $\begin{array}{c}\text { Pre- } \\
\text { Control }\end{array}$ & $\begin{array}{c}\text { Post-Control/ } \\
\text { Pre- } \\
\text { Intervention } \\
\text { (baseline) }\end{array}$ & $\begin{array}{c}\text { Post- } \\
\text { Interv } \\
\text { ention }\end{array}$ \\
\hline Scores & 47.69 & 49 & 49.93 \\
\hline $\begin{array}{c}\text { Differenc } \\
\text { e with } \\
\text { baseline }\end{array}$ & 1.31 & & 0.93 \\
\hline
\end{tabular}

Questions No. 3 and 5 about salty food and fast food consumption also had increased scores both in the control and intervention periods. The score increase of No. 5 was higher in the control period than in the intervention period. This situation may be because the majority of the respondents are women who are not employed but rather acting as housewives. Accordingly, they tend to eat at home, process their food, and control the amount of salt added to it (Mufidah, 2012). The scores of Question No. 4 about how often patients add salt, soy sauce, or sauce to their food decreased in the control period possibly because of the change in patients' compliance. At a certain time, people diagnosed with hypertension can comply with the rules of the treatment well, but may present different behavior at other times. The fluctuating compliance usually occurs in patients who do not have a strong personal awareness of the importance of adhering to these rules (Pujiyanto, 2008). However, the patients' compliance score of No. 4 increased after receiving peer assistance. According to Wati et al. (2015), the role of pharmacists in providing education and mentoring to patients can expand their knowledge and raise awareness of treatment adherence.

The total score of Question No. 6 about how often patients make an appointment for their next visit before leaving the clinic was close to the minimum score (29). Aside from the decrease in the control period by only 2 points, there was no significant fluctuation in the score because the respondents never made a follow-up appointment but visited the doctor only accordingly to the monthly schedule set by the Chronic Disease Management Program (CDMP) instead. The respondents would make an appointment only when they could not come on the day of the scheduled visit. The scores of Questions No. 7 about how often patients miss the scheduled meeting and No. 8 about how often they forget to repeat their medication increased in the control period but decreased in the intervention period. Such an increase is because the majority of the respondents are unemployed (79.3\%) or, in other words, they do not have a busy schedule that may interrupt the monthly appointment set by CDMP. Meanwhile, the score decline in the intervention period is due to a change in the CDMP's agenda during the fasting month. Six respondents did not know of this change and, therefore, they missed the appointment.

The score of Question No. 9 about how often patients run out of antihypertensive drugs did not change during the control period but decreased during the intervention period. Every month in the 
control period, patients were always given the medications for the next 30 days. Therefore, the possibility of running out of drugs was very small. The score decrease in the intervention period was caused by a change in the CDMP's schedule during the fasting month, and some respondents were not aware of this change. As a result, the respondents who missed the changed appointment ran out of antihypertensive drugs.

The score of Question No. 11 about how often patients choose not to take the medicines when they feel healthier increased during the control period and decreased during the intervention period. The score increase can be caused by the characteristics of the respondents who are predominantly female. Women usually pay more attention to their health than men (Depkes RI, 2013). Therefore, they tend to comply with the rules of the treatment even though they feel healthy. Meanwhile, the score decrease in the intervention period is because the intervention was carried out during the fasting month. According to Mughni (2007), fasting can reduce body weight, salt intake, and stress; hence, low blood pressure. It affects patients' decisions in taking antihypertensive drugs. Patients tend not to take medicine when their blood pressure drops because they are afraid of experiencing hypotension (Wati et al., 2015).

The score of Question No. 12 about how often patients choose not to take their medicines when they feel sick increased during the control and intervention periods. Respondents did not experience periods of pain due to the side effects of drugs or other diseases. The score of Question No. 14 about how often patients forget to bring their antihypertensive drugs when traveling away from home remained the same in the control period, but after receiving peer assistance, the compliance score was higher.

\section{The Influence of Peer Assistance on Medication Compliance}

Table III shows that the $p$ values of the pre-/post-control and the pre-/post-intervention differ significantly $(\mathrm{P}<0.005)$. It indicates that peer assistance appears not to influence treatment compliance among hypertensive patients. The results are in line with Utami et al. (2016), which conclude that leaflet and reminder do not affect the adherence of hypertensive patients. In this case, the reminder was provided every day for three months according to the respondents' medication schedule, but it was not delivered via phone calls. The results also affirm Saputri et al. (2016), which state that brief counseling - 5A and SMS motivation do not affect the compliance of hypertensive patients. The SMS motivation in the study was carried out every day until the second visit (post study).

Table IV. The difference test results of the Pre-/Post-Control and the Pre-/Post-Intervention

\begin{tabular}{cccc}
\hline & \multicolumn{3}{c}{ Scores } \\
\cline { 2 - 4 } & $\begin{array}{c}\text { Pre-Control } \\
\text { Post-Control/ } \\
\text { Pre-Intervention }\end{array}$ & $\begin{array}{c}\text { Post- } \\
\text { Intervention }\end{array}$ \\
\hline Average & 47.69 & 49 & 49.93 \\
\hline Minimum & 40 & 40 & 37 \\
\hline Maximum & 52 & 52 & 53 \\
\hline $\begin{array}{c}P \text { Values } \\
\text { (against post-control/ pre- } \\
\text { intervention) }\end{array}$ & 0.008 & & 0.039 \\
\hline
\end{tabular}

The results of this study are different from Varleta et al. (2017), which claim that SMS intervention can improve the medication adherence of hypertensive patients. In their research, the 
SMS contained educational information about healthy diet, salt consumption, medication schedule, and the importance of adhering to the rules of treatment, and it was sent once every 12 days for six months. The results of this study are also not in line with Yoisangadji et al. (2016), which affirm the relationship between peer assistance and medication compliance. In their research, peer assistance not only involved health workers but also relied on the role of family members. According to Firdaus (2012), effective peer assistance is supported by the good relationship and closeness between the medication supervisors and patients. Meanwhile, in this study, peer assistance was performed by the researchers. In other words, the medication supervisors have neither familial relationship with nor closeness to the patients.

The analysis revealed significant differences between patients who did or did not receive the role of a medication supervisor. The increase in compliance score was higher in patients who did not receive it than the ones who did. Increased scores in the control period can be due to the characteristics of patients who are predominantly female. Women pay more attention to their health than men (Depkes RI, 2013), and when in sickness, women seek treatment more often than men (Notoatmodjo, 2010). There is also another supporting factor that led to an increase in compliance score in the control period, namely when filling out the questionnaire on medication compliance, respondents were indirectly reminded about the rules of their ongoing treatment. A smaller increase in the adherence score during the intervention period is likely because the intervention was performed during the fasting month. Fasting can cause a decrease in blood pressure and when they feel this drop, they prefer not to take antihypertensives. According to Wati et al. (2015), fasting is one of the most reasons that patients claim as the cause of their non-compliance. In the fasting month, there was a change in the CMDP's schedule that some patients did not know of and, as a consequence, they missed their monthly appointment and ran out of their stock of drugs.

\section{CONCLUSION}

The average compliance score of the hypertensive patients at two primary health services increases from the control period to the intervention period: 47.69 during pre-control to 49 during post-control/pre-intervention and to 49.93 during post-intervention. Peer assistance does not affect the treatment compliance of hypertensive patients at two primary health services in Purwokerto because the adherence during both of the control and intervention period differed significantly with $P$ values of 0.008 and 0.039 , respectively.

\section{ACKNOWLEDGMENT}

Authors would like to thank the LPPM, Universitas Jenderal Soedirman.

\section{REFERENCES}

Alfian. R., 2015. Layanan pesan singkat pengingat untuk meningkatkan kepatuhan dan menurunkan tekanan darah pasien hipertensi di RSUD Dr. H. Moch Ansari Saleh Banjarmasin. Media Farmasi, 12(1): 129-138.

Agrina, Sunarti S. S., Riyan H., 2011. Kepatuhan lansia penderita hipertensi dalam pemenuhan diet hipertensi, Jurnal SOROT Universitas Riau, 6 (1).

Cheong, AT., Tong, SF., Sazlina S.G., 2015. Validity and reliability of the malay version of the hillbone compliance to high blood pressure therapy scale for use in primary healthcare setting in Malaysia: A cross-sectional study, Malaysian Family Physician, 10 (2): 36-44.

Chobanian, A.V., 2003. Seventh report of the joint national committee on prevention, detection, evaluation, and treatment of high blood pressure: The JNC 7 Report, National Institutes of Health, 289: (25): 60-72.

Depkes RI, 2009. Undang-Undang No 36 Tahun 2009 Tentang Kesehatan, Departemen Kesehatan Republik Indonesia, Jakarta. 
Depkes RI., 2013. Riset Kesehatan Dasar (RISKESDAS) Dalam laporan nasional, badan penelitian dan pengembangan kesehatan, Departemen Kesehatan Republik Indonesia, Jakarta.

Dinas Kesehatan Banyumas, 2015. Profil Kesehatan Kabupaten Banyumas 2014, Dinkes Banyumas, Purwokerto.

Firdaus, K.M.A., 2012. Pengaruh peranan pengawas menelan obat (Pmo) terhadap keberhasilan pengobatan tb paru di wilayah kerja puskesmas Baki Sukoharjo, Skripsi, Fakultas Ilmu Kesehatan Universitas Muhammadiyah Surakarta, Surakarta.

Filipovský, J., Widimský, J., Špinar, J., 2014. Summary of 2013 ESH/ESC Guidelines for the management of arterial hypertension. Cor Vasa, 56: e494-e518.

Gudmundsdottir, H., Hoieggen, A., Stenehjem, A., Waldum, B., Os, I., 2012. Hypertension in Women: Latest Findings and Clinical Implications. Ther Adv Chronic Dis: 3 (3):137-146.

Gumi, V.C, Larasant L.P.F, N.N.W. 2013. Identifikasi drug related problems pada penanganan pasien hipertensi di upt puskesmas jembrana. Jurnal Farmasi Udayana, 2 (3): 50-58.

Kemenkes RI, 2009. Keputusan Menteri Kesehatan Republik Indonesia Nomor 364/Menkes/Sk/V/2009 Tentang Pedoman Penanggulangan Tuberkulosis (Tb) Menteri Kesehatan Republik Indonesia, Kemenkes RI, Jakarta.

Mufidah, N. L., 2012. Pola konsumsi masyarakat perkotaan: studi deskriptif pemanfaatan foodcourt oleh keluarga, BioKultur, I (2): 157-178.

Mughni, A., 2007. Pengaruh puasa ramadhan terhadap faktor-faktor risiko aterosklerosis studi pada profil lipid, gula darah, tekanan darah dan berat badan, Master Thesis, Program Pasca Sarjana Magister Ilmu Biomedik dan Program Pendidikan Dokter Spesialis I Ilmu Bedah Universitas Diponegoro, Semarang.

Mursiany, A., Ermawati N., Oktaviani N., 2013. Gambaran penggunaan obat dan kepatuhan mengkonsumsi obat pada penyakit hipertensi di instalasi rawat jalan RSUD Kraton Kabupaten Pekalongan Tahun 2013. Laporan Penelitian Dosen, Prodi Farmasi Universitas Pekalongan.

Notoatmodjo, S., 2010. Promosi kesehatan teori dan aplikasi, Rineka Cipta, Jakarta.

Pujiyanto, 2008, Faktor sosio ekonomi yang mempengaruhi kepatuhan minum obat anti hipertensi, Jurnal Kesehatan Masyarakat Nasional, 3 (3): 139-144.

Putri, R.A., 2012. Analisis efektivitas pemberian konseling dan pemasangan poster terhadap tingkat kepatuhan dan nilai tekanan darah pada pasien hipertensi di Puskesmas Bakti Jaya Kota Depok, Master Thesis, Fakultas Matematika dan Ilmu Pengetahuan Alam, Universitas Indonesia, Jakarta.

Rahmawati, M., and Mutmainah, N., 2010. Hubungan antara kepatuhan penggunaan obat dan keberhasilan terapi pada pasien hipertensi Di Rumah Sakit Daerah Surakarta Tahun 2010, Pharmacon, 11(2): 51-56.

Ramli, A., Nur, S.A., Thomas, P., 2012, Medication adherence among hypertensive patients of primary health clinics in Malaysia, Patient Preference and Adherence Jornal, $6: 613-622$.

Saputri, Z. G., Akrom, Endang D., 2016, Tingkat kepatuhan antihipertensi dan pengontrolan tekanan darah pasien rawat jalan RS PKU Muhammadiyah Bantul, Yogyakarta yang Mendapatkan Brief Counseling-5a dan SMS Motivasional, Jurnal Farmasi Sains dan Komunitas, 3 (2): 67-72.

Saseen, J.J., and Carter, B.L., 2015, Hypertension dalam Wells, B.G., DiPiro, J.T., Schwinghammer, T.L., and DiPiro, C.V., Pharmacotharapy Handbook, Ninth Edition, Mcgraw Hill Education, New York, 87-101.

WHO, 2003, Adherence To Long-Term Therapies, WHO Library Cataloguing, Switzerland, 3.

Utami R.A., Nurul Annisa, Victoria Y.F., Adam M.R., 2016. Pengaruh pemberian leaflet dan reminder terhadap outcome terapi dan kepatuhan pasien hipertensi geriatrik di RSUD A. Wahab Sjahranie Samarinda, Prosiding Seminar Nasional Kefarmasian Ke-4, Samarinda.

Varleta, P., Acevedo, M., Akel, C., Salinas, C., Navarrete, C., García, A., Echegoyen, C., Rodriguez D., Gramusset L., Leon S., Cofré P., Retamal R., Romero K., 2017, Mobile phone text messaging improves antihypertensive drug adherence in the community, J Clin Hypertens 2017 (19) :1276-1284. 
Wati, M, R., Mustofa, Puspitasari, I., 2015, Pengaruh konseling apoteker komunitas terhadap pasien hipertensi, Jurnal Manajemen dan Pelayanan Farmasi, 5 (1) : 48-55.

Yacob, G.L. and Leonelo E.B., 2015, Drug Side Effect Symptoms and Adherence to Antihypertensive Medication, American Journal of Hypertension. 29(6):773-779.

Yoisangadji, A.S., Maramis, F.R.R., Rumayar, A.A., 2016. Hubungan antara pengawas menelan obat (PMO) dan peran keluarga dengan kepatuhan minum obat pada pasien Tuberkulosis di wilayah kerja puskesmas sario kota Manado, Pharmacon, 5 (2): 138-143.

Shen Y., X.Peng., M.Wang., X.Zheng., G.Xu., L Lü., K .Xu., B.Burstrom., K. Burstrom., and J. Wang., 2017. Family member-based supervision of patients with hypertension: a cluster randomized trial in rural China, Journal of Human Hypertension, 31 : 29-36. 